\title{
Special Section in Curriculum Matters 2016-Call for Expressions of Interest
}

Expressions of interest are sought for proposals to guest edit a special section of Curriculum Matters.

A special section will address a specific theme in the curriculum field, which includes curriculum theory, policy and curriculum development, classroom practice and pedagogy, and disciplinebased inquiry. It may focus on a particular educational sectorearly childhood, primary, secondary or tertiary education-or take a cross-sector view. The articles within a special section will a contribution to research and thinking in the curriculum field. A special section needs to be relevant for a range of Curriculum Matters audience groups, which include teachers, teacher educators, educational researchers and curriculum theorists. It will normally have between four and six articles, relating to a particular theme.

A Guest Editor will work with contributors to ensure the quality of manuscripts and manage a process of blind peer review for a special section. The Guest Editor will also ensure cohesion across special section contributions and write an Introduction for the section. He or she will seek advice from the Editor, as appropriate, in coordinating the section. Previous academic editing experience would be an advantage.

\section{Key dates}

- Proposals to guest edit a special section for the 2016 edition of Curriculum Matters are due 31 July 2015.

- A decision on proposals for a special section in 2016 will be made by the end of August, 2015. 
- Manuscripts for a special section (that have been through a peer review and revision process) will be due on 31 July 2016.

More detailed guidelines for special sections are available from the Curriculum Matters Editor.

Expressions of interest in guest editing a special section of Curriculum Matters and requests for guidelines should be directed to:

Dr Jane Abbiss

Curriculum Matters Editor

University of Canterbury

Christchurch 8024

New Zealand

jane.abbiss@canterbury.ac.nz

Ph: 033458465 